\title{
Migratory patterns in hawksbill turtles described by satellite tracking
}

\author{
L. A. Hawkes ${ }^{1,2, *}$, J. Tomás ${ }^{3,4}$, O. Revuelta ${ }^{3}$, Y. M. León ${ }^{5}$, J. M. Blumenthal ${ }^{6}$, \\ A. C. Broderick ${ }^{4}$, M. Fish ${ }^{7}$, J. A. Raga ${ }^{3}$, M. J. Witt ${ }^{2,4}$, B. J. Godley ${ }^{4}$ \\ ${ }^{1}$ School of Biological Sciences, Bangor University, Deiniol Road, Bangor, Gwynedd LL57 2UW, UK \\ ${ }^{2}$ Environment and Sustainability Institute and ${ }^{4}$ Marine Turtle Research Group, Centre for Ecology and Conservation, \\ University of Exeter, School of Biosciences, Treliever Road, Penryn, Cornwall TR10 9EZ, UK \\ ${ }^{3}$ Marine Zoology Unit, Cavanilles Institute of Biodiversity and Evolutionary Biology, University of Valencia, PO Box 22085, \\ Valencia 46071, Spain \\ ${ }^{5}$ Instituto Tecnologico de Santo Domingo, Area de Ciencias Basicas, INTEC, Avenida de Los Próceres, \\ Los Jardines del Norte 10602, Santo Domingo, Dominican Republic \\ ${ }^{6}$ Department of the Environment, Cayman Islands Government, PO Box 10202, Grand Cayman KY1-1002, Cayman Islands \\ ${ }^{7}$ World Wildlife Fund, 409 Granville Street, Suite 1588, Vancouver, British Columbia V6C 1T2, Canada
}

\begin{abstract}
The advent of telemetry has improved knowledge of the spatio-temporal distribution of marine species of conservation concern. Among the sea turtles, the movements of the hawksbill turtle Eretmochelys imbricata are among the least well described. We tracked 10 adult female hawksbill turtles by satellite after nesting in the Dominican Republic (DR) and describe a dichotomy in patterns of movement: some $(\mathrm{n}=2)$ turtles remained in the DR, while others migrated to waters off Honduras and Nicaragua $(n=5)$ and the Bahamas $(n=1)$. Transmitters on 2 turtles failed during migration, before they reached their final foraging grounds. We present results from long tracking durations for 3 turtles, including 3 entire remigration intervals, highlighting foraging ground and nest-site fidelity. Threats to hawksbill turtles are not well documented for Nicaragua or neighbouring Honduras and represent a major information gap. We suggest that directing conservation efforts to regionally important foraging areas, such as those in Nicaragua, and strengthening national conservation in each nation with significant hawksbill nesting offers a clear way forward for the conservation of hawksbill turtles in the region.
\end{abstract}

KEY WORDS: Satellite tracking $\cdot$ Hawksbill turtle $\cdot$ Caribbean $\cdot$ Conservation planning $\cdot$ Fidelity

\section{INTRODUCTION}

The successful management of marine species of conservation concern is particularly challenging to managers if the species are highly migratory, often necessitating the coordination of a network of nations and their corresponding legal frameworks (Fanning et al. 2007, Guerreiro et al. 2010). Fortunately, a boom in the technology required to remotely track individuals has come about in the last 3 decades (Hooker et al. 2007, Kooyman 2007, Hart \& Hyrenbach 2009, Bograd et al. 2010, Block et al.
2011). This has allowed unrivalled insights into the movements of animals over months and even years. Such insights have begun to provide a robust framework with which managers can predict the spatiotemporal occurrence of species of conservation concern. Although management challenges are compounded in the marine realm, where it may be logistically harder to enforce protective measures (Game et al. 2009), patterns of distribution for many of the large marine vertebrates have now been described, albeit usually with small sample sizes and often for specific populations. We know perhaps the most 
about the marine turtles (Godley et al. 2008), with all 7 species having been tracked.

The hawksbill turtle Eretmochelys imbricata is, however, one of the least understood of the marine turtles. It is usually found associated with coral reefs (Meylan 1988, Anderes \& Uchida 1994, Hill 1998, Leon \& Bjorndal 2002, Obura et al. 2010) and is of considerable conservation interest (IUCN Redlist, www.iucnredlist.org, accessed 12 August 2010). Modern populations in the Caribbean are thought to be at relictual levels (McClenachan et al. 2006) as a result of hunting and trade in the meat, eggs and keratinous shell plates ('tortoiseshell'; Carillo et al. 1999). Most international trade ceased with the listing of all species of marine turtles on Appendix I by the Convention on International Trade of Endangered Species (CITES) in 1981. Some legal turtle fisheries still exist in the Caribbean (e.g. Richardson et al. 2006b), and turtles are also caught accidentally in commercial and artisanal fishery operations (Wallace et al. 2010). Conservation efforts at nesting grounds, however, appear to be paying off, and increases in hawksbill nesting numbers have been documented in Puerto Rico (Meylan 1999, Diez \& Van Dam 2007), Antigua (Richardson et al. 2006a), Barbados (Beggs et al. 2007), Guadeloupe (Kamel \& Delcroix 2009), Brazil (Marcovaldi \& Chaloupka 2007) and Seychelles (Allen et al. 2010). Nevertheless, little information about the spatio-temporal distribution of hawksbill turtles at sea has been published (see Godley et al. 2008 for review).

The Dominican Republic $\left(D R, 18.9^{\circ} \mathrm{N},-70.7^{\circ} \mathrm{W}\right)$ in the Greater Antilles, Eastern Caribbean, hosts regionally significant numbers of nesting hawksbill turtles (Leon \& Diez 1999, McClenachan et al. 2006, Revuelta et al. 2012). Hawksbill turtles nest sporadically along the coast of the country, with the marked exception of 2 nesting 'hotspots': Jaragua National Park (in southwestern DR, 5 to 25 nests per year) and Saona Island (Del Este National Park, in southeastern DR, 100 nests per year; Revuelta et al. 2012). Direct take of hawksbill turtles (for shell, meat or eggs) is considerable at both major rookeries, and between 20 and $60 \%$ of nests are harvested illegally each year at Saona Islands (Revuelta et al. 2012). When compared with $30 \mathrm{yr}$ ago, current nesting numbers suggest a profound decline has occurred (perhaps as much as $90 \%$; Revuelta et al. 2012, see also Ottenwalder 1981). Nothing is known about their postnesting migratory movements and targeted feeding grounds, and tissue samples from the DR have not yet been included in Caribbean-wide genetic studies (Bowen et al. 2007, Blumenthal et al. 2009a).
In the present study, we (1) used satellite tracking to locate foraging areas for adult female hawksbill turtles following nesting in the DR, (2) used remotely sensed environmental data to describe their habitat preferences and (3) described the fidelity exhibited by hawksbill turtles to foraging sites, nesting sites and migratory routes. We discuss these findings in the context of regional conservation and management.

\section{MATERIALS AND METHODS}

\section{Tracking}

Hawksbill turtles were equipped with satellite tracking units in the DR between August and December 2008 ( $\mathrm{n}=6$ Wildlife Computers SPOT5 tags and $\mathrm{n}=2$ Sirtrack Kiwisat 101 tags) and August and September 2009 ( $\mathrm{n}=2$ Sirtrack Kiwisat 101 tags; Table A1 in Appendix 1) after they were encountered nesting on the beach. A total of 8 turtles were tagged at Saona Island (southeastern DR), 1 at Jaragua National Park (southwestern DR) and 1 at San Pedro de Macoris (South DR). Transmitters were attached to the second vertebral scute of the turtles' carapace using fast-setting epoxy resin and covered with a layer of anti-fouling paint. Transmitter data were downloaded and managed using the Satellite Tracking and Analysis Tool (STAT) from SEATURTLE.ORG (Coyne \& Godley 2005). Data were subsequently filtered, retaining the best daily location from Argos location classes 3, 2, 1 and A (Witt et al. 2010b), retaining data with turning angles $>25^{\circ}$ (location errors often being associated with acute 'off-track' turning angles), transit speeds $<5 \mathrm{kph}$ and locations over waters $>1 \mathrm{~m}$ deep (removing locations corresponding to nesting events and erroneous locations on land).

Remotely sensed environmental data describing sea surface temperature (monthly from AVHRR; http://noaasis.noaa.gov/NOAASIS/ml/avhrr.html) and depth (GEBCO; www.gebco.net) were obtained for each location, and the last highest quality location class received each day from each turtle was carried forward to analyses. Summary statistics are the grand median of medians per turtle.

\section{Home ranges}

For each turtle, we calculated the distance from the deployment site to each subsequent location (the displacement distance) and plotted these against time (Fig. 1, see also Blumenthal et al. 2006). This 
approach shows periods of migration (persistent movement away from the deployment location; as steep increases in displacement) as distinct from sedentary periods (inter-nesting and foraging; nearly horizontal in slope). Foraging and inter-nesting data can then be extracted and used in further analyses. A foraging or inter-nesting home range was only considered valid if the turtle was tracked arriving and remaining at a site for at least 80 d (a 'complete' home range; Hawkes et al. 2011). We estimated the size of the home range occupied by hawksbill turtles while they were forag-

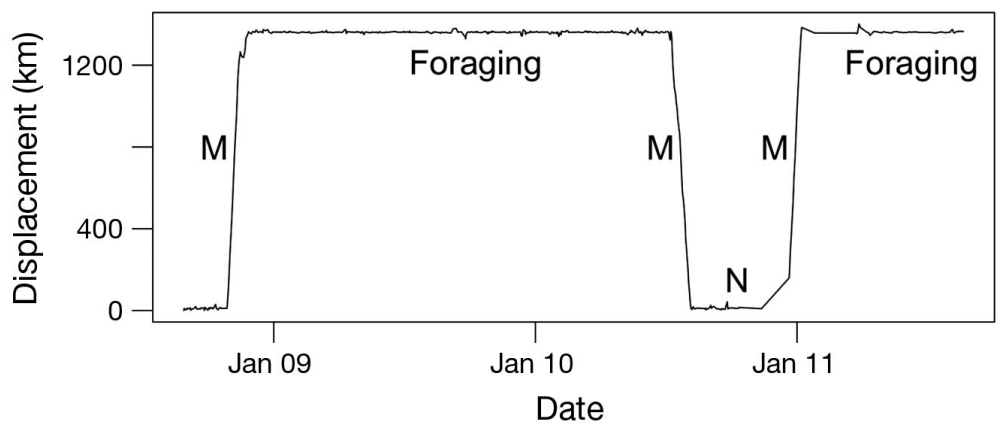

Fig. 1. Displacement of Turtle g showing migration away from the nesting site in the Dominican Republic (vertical sections, labelled ' $\mathrm{M}$ '), followed by an entire foraging season in Nicaragua (horizontal section), then migration back to the DR ('M') to nest again 2 yr later (' $\mathrm{N}$ '). The turtle returned to her foraging ground again after nesting (horizontal section) ing using (1) minimum convex polygons (MCPs) and (2) $\alpha$-hulls (Burgman \& Fox 2003). MCPs are very simple home-range estimators, drawing the smallest convex polygon that incorporates all of the filtered locations. $\alpha$-hulls measure the area encompassed in a triangulated network of all data points after accounting for a multiplier of the mean triangle side length $(\alpha)$ and discarding triangles with greater side lengths. While MCPs can include areas of habitat that are probably not used by the animal (Burgman \& Fox 2003), $\alpha$-hulls can objectively remove these areas from the total home range calculation. We generated both MCPs and $\alpha$-hulls using custom MATLAB programming scripts. Data were mapped in ArcGIS 9.2 (ESRI). For each home range, we also calculated the centroid position, defined as the median latitude and longitude for all filtered location data.

\section{RESULTS}

\section{General movements and strategies}

Turtles exhibited 2 general patterns of migration (Fig. 2): (1) regional movements within the waters of the DR ('regional' turtles, $\mathrm{n}=2$ ) and (2) 'international' movements west to the coastal shelf off Honduras and Nicaragua $(\mathrm{n}=5)$ and north to the Turks and Caicos Islands and northwestward to the Bahamas $(n=1)$. Transmitters on 2 turtles failed during migration, before they reached their final foraging grounds, with one turtle last located in Jamaican waters $1017 \mathrm{~km}$ southwest of the DR and the other turtle last located in Puerto Rico waters $109 \mathrm{~km}$ east of the DR.

For 'regional' turtles (Table A1, Fig. 2a,b), the location data derived from the attached transmitters (both deployed in 2008) suggested that the turtles had

reached foraging areas after migrating for 11 and $14 \mathrm{~d}$, respectively, 304 and $228 \mathrm{~km}$ west of their deployment site (the distance from deployment to the centroid of their foraging areas). The turtles travelled at 16 and $28 \mathrm{~km}$ per day, respectively. These turtles remained in these foraging sites for 497 and $463 \mathrm{~d}$, respectively, until no more messages were received.

'International' turtles $(\mathrm{n}=6$; Table A1, Fig. 2c-j) migrated outside of DR waters, travelling for $44 \mathrm{~d}$ (mean value, range: 11 to $92 \mathrm{~d}$ ) to foraging grounds $1401 \mathrm{~km}$ away (median value, range: 785 to $1669 \mathrm{~km}$ ) in the waters of Honduras $(n=1)$, Nicaragua $(n=4)$ and the Bahamas $(n=1)$. Turtles travelled at $36 \mathrm{~km}$ per day (grand median value, range: 8 to $75 \mathrm{~km}$ per day, $\mathrm{n}=6$ ). All 6 turtles migrated westward of the DR, with 5 heading to foraging grounds in Honduras and Nicaragua on a similar bearing (the best daily location bearings during migration for Turtle i were significantly correlated with those of Turtles $d, h$ and $j_{\text {; }}$ Spearman's rho, $p<0.05)$. Approximately due south of Haiti, their routes diverged, differing by up to $400 \mathrm{~km}$ (north to south) before reaching final foraging destinations in Honduras ( $\mathrm{n}=1$ turtle) and the Miskito Cayes, Nicaragua ( $\mathrm{n}=4$ turtles). The 6 th turtle ( $\mathrm{f}_{;}$ Fig. 2) headed north to the Turks and Caicos Islands, where it remained for $49 \mathrm{~d}$, before departing and migrating onward to the Bahamas (Fig. A1). In the Bahamas, Turtle $f$ made a looping migration around the most easterly islands, stopping at 3 different sites before settling in a discrete foraging area until its transmitter terminated (366 d after arrival in the Bahamas).

\section{Environmental preferences}

During migration, turtles were located over waters $1044 \mathrm{~m}$ deep (grand median of all turtles, inter- 
quartile range [IQR] 278 to $1469 \mathrm{~m}$, maximum water depth $4138 \mathrm{~m}$ ) and in sea surface temperatures of $28.2^{\circ} \mathrm{C}$ (grand median of all turtles, IQR 25.1 to $29.0^{\circ} \mathrm{C}_{i}$ Fig. 3a,b). Regional turtles migrated to foraging grounds over shallower seas than international
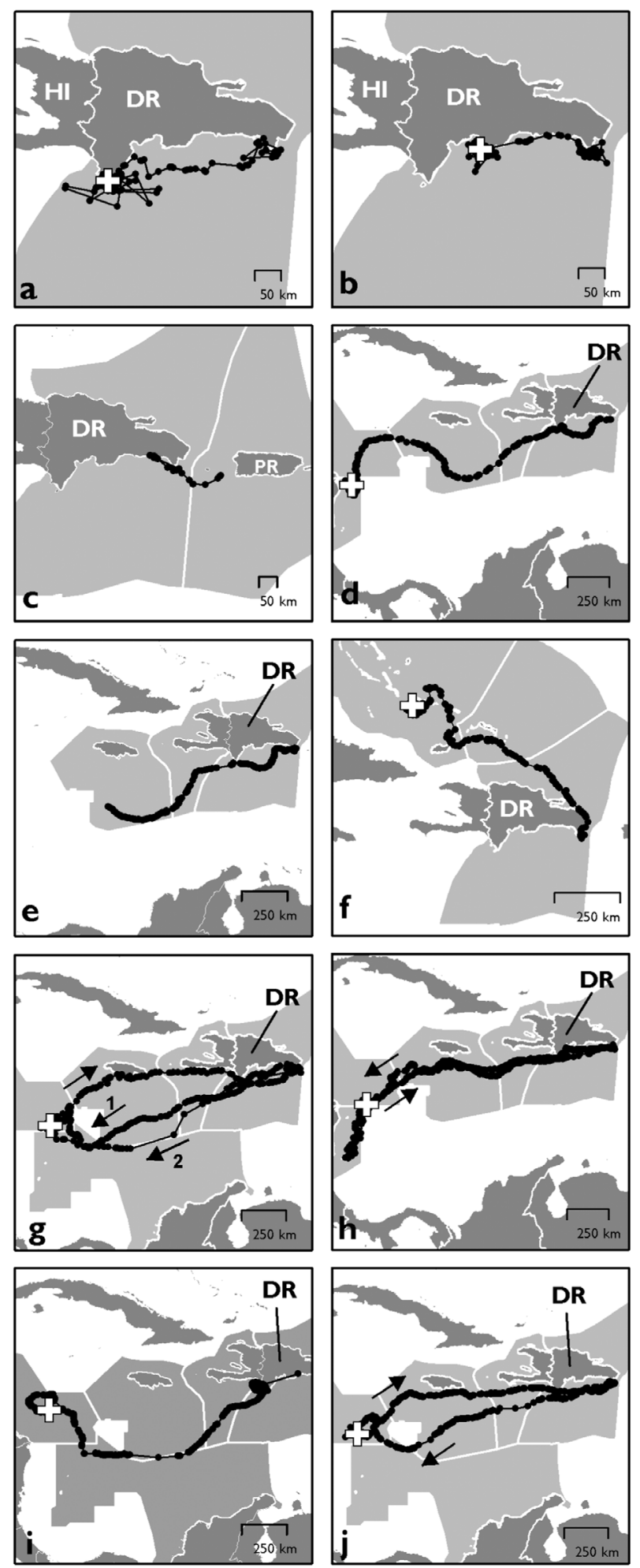

turtles (median 801 and $75 \mathrm{~m}$ for regional Turtles a and $b$, respectively, vs. grand median $1322 \mathrm{~m}$ for international turtles). During foraging, turtles were located offshore on the coastal shelf in waters that were significantly shallower (grand median $54 \mathrm{~m}$, IQR 27 to $109 \mathrm{~m}$ ) than waters that they had migrated over (Wilcoxon-Mann-Whitney 2-sample rank sum test $U=76, \mathrm{p}<0.05)$ but that were not significantly warmer (grand median value for all turtles tracked to foraging grounds, 27.6 to $27.9^{\circ} \mathrm{C} \mathrm{IQR}_{i}$ WilcoxonMann-Whitney 2-sample rank sum test, $\mathrm{p}<0.05$; Fig. 3c,d). Regional turtles likely foraged in shallower waters than international turtles (regional turtles: 7 and $58 \mathrm{~m}$, respectively, vs. international turtles: grand median $78 \mathrm{~m}$ ) but that did not differ in sea surface temperature $\left(26.5\right.$ and $27.8^{\circ} \mathrm{C}$, respectively, vs. grand median $27.8^{\circ} \mathrm{C}$ ).

\section{Home range size}

The median home range sizes for 3 turtles tracked for the entire foraging period before re-migrating to breeding grounds were 1022, 4422 and $2122 \mathrm{~km}^{2}$, respectively (using $\alpha$-hulls; occupied for 593, 891 and 594 d, respectively, Fig. 4, Table A1). Home ranges were almost an order of magnitude larger when estimated using MCPs $\left(2455,18190\right.$ and $10071 \mathrm{~km}^{2}$, respectively), probably due to excursions outside of a core foraging area that were less likely to be included by the $\alpha$-hull method. Foraging areas for all turtles were located $80 \mathrm{~km}$ from the coast (grand median of all turtles, range 4 to $195 \mathrm{~km}$ ) and were not normally in protected waters (grand median $0 \%$,

Fig. 2. Post-nesting migrations of 10 hawksbill turtles from the Dominican Republic (DR); letters match turtles in Table A1 in Appendix 1. Two turtles $(a, b)$ remained in DR waters, and 8 turtles $(\mathrm{c}, \mathrm{d}, \mathrm{e}, \mathrm{f}, \mathrm{g}, \mathrm{h}, \mathrm{i}, \mathrm{j})$ moved into other Caribbean nations' waters. Seven turtles moved westwards from the DR $(d, e, f, g, h, i, j), 5$ moved into Nicaraguan and Honduras waters, 1 (Turtle f) moved north through the Turks and Caicos Islands to the Bahamas and 1 turtle moved west but transmissions stopped in Jamaican waters. Black dots: filtered locations received from turtles; white crosses: median centroid of foraging area for turtles that were tracked to foraging areas (the transmitters on Turtles $\mathrm{c}$ and e failed en route). Note different scale bars. Light grey shading shows the extent of Exclusive Economic Zones (EEZs) in the Caribbean through which each turtle travelled. Repeat migrations from foraging areas back to nest again are shown for 3 turtles $\left(\mathrm{g}, \mathrm{h}, \mathrm{j}_{i}\right.$ arrows indicate direction of movement). Turtle $\mathrm{g}$ was tracked returning to her foraging ground a second time (routes to migration indicated for Year 1 [2008] and Year 2 [2010]). HI: Haiti 

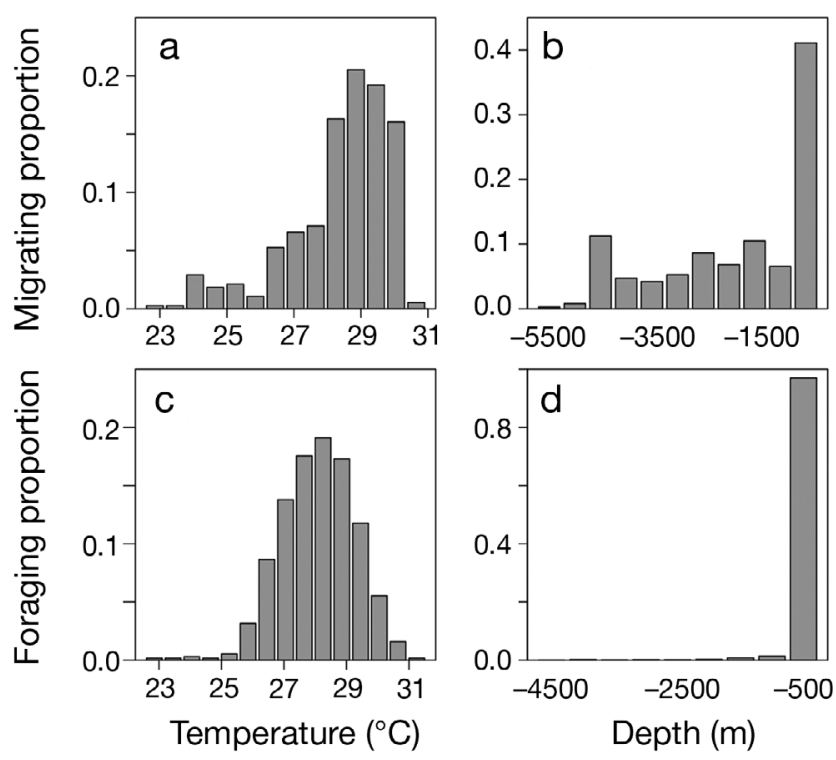

Fig. 3. Environmental preferences of hawksbill turtles during migration $(a, b)$ and foraging $(c, d)$, showing sea surface temperature $(\mathrm{a}, \mathrm{c})$ and depth $(\mathrm{b}, \mathrm{d})$ range 0 to $95.2 \%$ of locations in marine protected areas; Fig. 4). Considering all home ranges (including 'incomplete home ranges', $\mathrm{n}=8$; Table A1), home range size was not significantly correlated with carapace size (Pearson's $t=0.98, \mathrm{p}>0.05$ ) nor duration for which the turtle was tracked in the home range (Pearson's $t=1.55, \mathrm{p}>0.05)$.

\section{Fidelity}

Turtles exhibited marked foraging site fidelity, remaining in core home ranges of $\sim 2000 \mathrm{~km}^{2}$, with the exception of 2 turtles (Turtles $h$ and $j$ ) that made small excursions adjacent to the shore from their core foraging areas, leading to inflated MCPs compared to their $\alpha$-hulls. Three turtles were tracked from arrival at their foraging grounds until their departure to breed and nest again in the DR, migrating back in 28, 34 and $37 \mathrm{~d}$, respectively (Fig. 2g,h,j). One turtle was tracked for the duration of a second nesting sea-
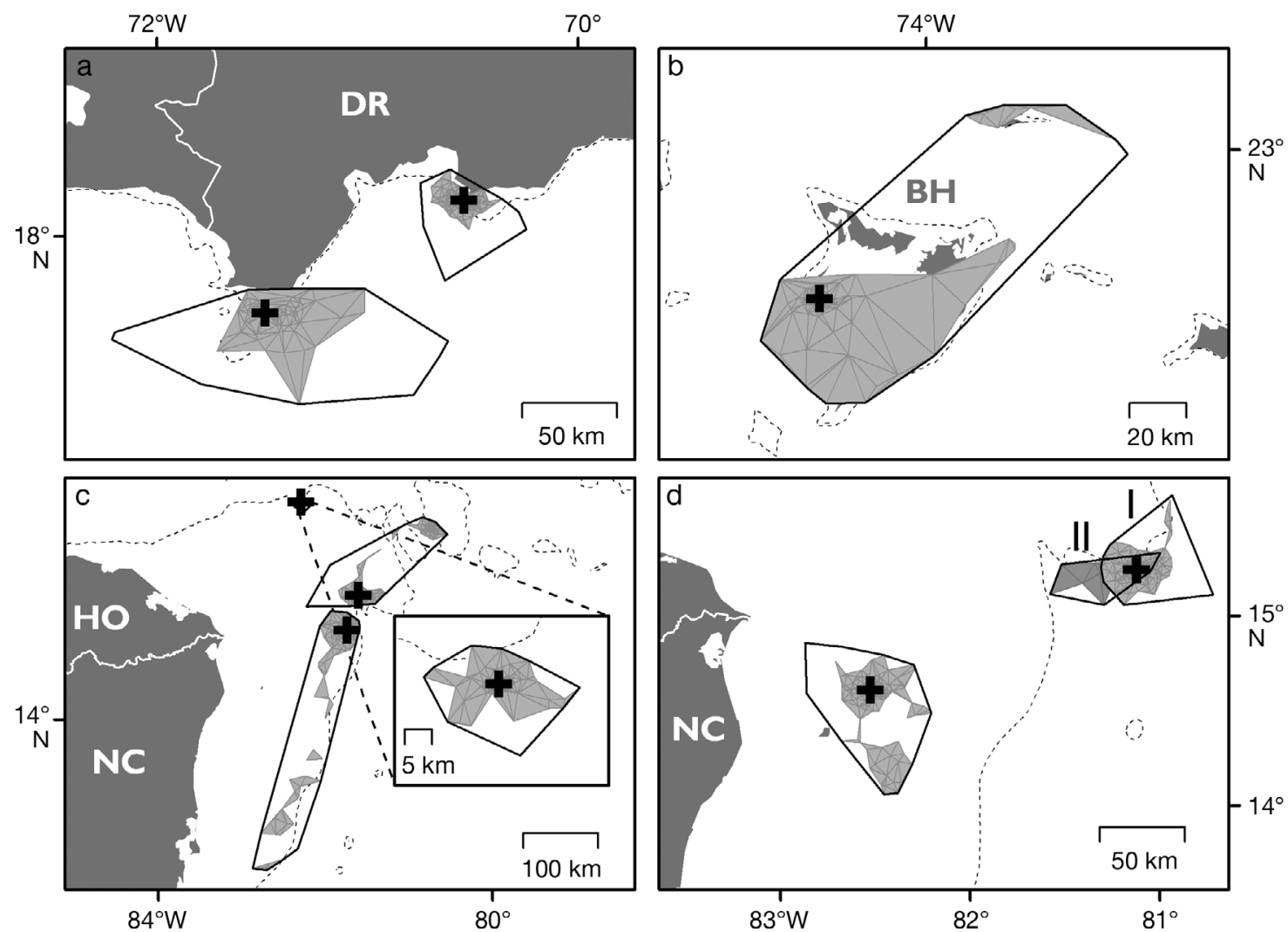

Fig. 4. Home ranges of hawksbill turtles: minimum convex polygons (-), $\alpha$-hulls (light grey polygons) and median centroid of occupation $(\boldsymbol{+})$ for $(\mathrm{a})$ regional turtles $(\mathrm{n}=2$; Turtles $\mathrm{a}$ and $\mathrm{b}$ ) located off the southern coast of the Dominican Republic (DR); (b) Turtle $\mathrm{f}$ in the Bahamas (BH); (c) 3 international turtles (h, i and j) located off Nicaragua (NC) or Honduras (HO) (inset: map of the home range for Turtle $i$, which occupied a particularly small home range); and (d) foraging home range for Turtle $d$ and $2 \mathrm{yr}$ home ranges for Turtle $\mathrm{g}$ that returned to within $322 \mathrm{~m}$ of its original foraging area after a remigration interval, denoted I and II, respectively. Note different scales. Dashed light grey line: $200 \mathrm{~m}$ bathymetric contour 
son (134 d) and migrated back to the same Nicaraguan foraging ground in $20 \mathrm{~d}$, where the tag stopped transmitting after $440 \mathrm{~d}$. Insights into interseasonal nesting site fidelity were possible for 2 turtles that migrated back to within $300 \mathrm{~m}$ and $3.2 \mathrm{~km}$, respectively, of their Year 1 nesting centroid of occupation (Fig. 5). Two of the 3 remigrant turtles (Fig. 2g,j) did not use the same route for their return migration, migrating instead up to $280 \mathrm{~km}$ distant (south and north, respectively) from their original tracks but reaching the same areas in the DR they were originally deployed in (Saona island, $\sim 24 \mathrm{~km}$ across).

\section{DISCUSSION}

\section{Movement patterns}

Our data add to the picture of movement for Caribbean hawksbill turtles, supporting the hypothesis of a migratory dichotomy in which some turtles remain in waters proximate to the nesting beach and others migrate to foreign waters, many to the Miskito Cayes, off Nicaragua and Honduras. This has also been observed for hawksbill turtles from Barbados, Bermuda, Costa Rica, Cuba and Puerto Rico (Horrocks et al. 2001, Troëng et al. 2005, Van Dam et al. 2008, Horrocks et al. 2011, Meylan et al. 2011, Moncada et al. 2012). It seems possible that there could be an oceanographic component to this pattern if the movements of hatchling and small juvenile hawksbill sea turtles are driven by ocean currents (Luschi et al. 2003, Blumenthal et al. 2009a, Godley et al. 2010).
For example, the Caribbean current empties from the Atlantic Ocean flowing in a westwards direction through the Caribbean, and if hatchling and juvenile turtles do not continue past the Yucatan peninsula, Mexico, into the Gulf of Mexico, they could instead settle out on the large offshore bank in the waters of Nicaragua and Honduras, and these could ultimately become adult foraging habitats. However, movement between multiple juvenile and adult foraging areas cannot yet be ruled out. The body of tracking data collected describing marine turtle migrations is now beginning to show that marine turtles regularly interact with oceanic currents (Luschi et al. 2003, Gaspar et al. 2006, Girard et al. 2006, Godley et al. 2008, Girard et al. 2009, Shillinger et al. 2012), but the extent to which they are passively carried, versus actively choose surface currents, is not well understood. Likewise, it was not possible in the present study to determine the extent to which this might have been the case for hawksbill turtles from the DR.

\section{Site fidelity}

Adult female hawksbill turtles from the DR do not always appear to exhibit strong fidelity to migratory routes, varying from original tracks by hundreds of kilometres, although they demonstrate remarkable goal orientation, arriving at the same destinations from different migratory routes. It is possible that as turtles cross the Caribbean current between Jamaica and Honduras, where the current is strongest, they may be displaced from an 'ideal' track and have to
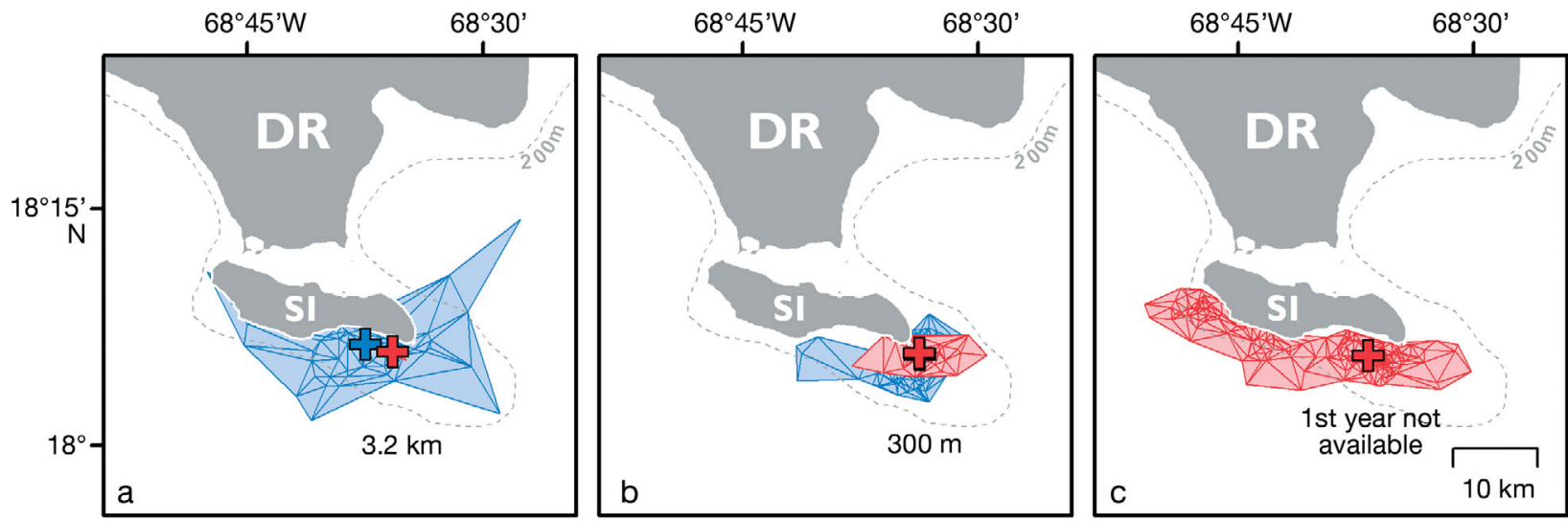

Fig. 5. Home ranges occupied during nesting for (a) Turtle g, (b) Turtle h and (c) Turtle j, which were tracked over a remigration interval returning to breed again, showing (shaded polygon) $\alpha$-hulls and ( + ) median centroid of occupation for first year (blue) and second year (red) of tracking (first year centroid is obscured by second year centroid in panel b). Distances between centroids are indicated for (a) and (b); the turtle in (c) departed immediately following transmitter attachment in Year 1. Original release site, Saona Island (SI), is indicated. DR: Dominican Republic 
make some compensation for drift (Chapman et al. 2011), resulting in the observed deviations from previous tracks. However, the results of our tracking confirm remarkable site fidelity, both intra and interannually, to foraging and nesting grounds. Foraging home ranges appear to be larger than was previously thought for hawksbill turtles (Meylan et al. 2011), but this may be a result of our exceptionally long tracking durations (Hawkes et al. 2011), suggesting that other estimates may have been too small. Taken together, these data suggest that many adult female hawksbill turtles should be found in the same foraging home ranges year after year, leaving only to breed every few years.

\section{Assessment of habitat type and threats}

The hawksbill turtles tracked in the present study (both regional and international turtles) occupied deeper waters in their foraging grounds than expected based on previously published data (Van Dam \& Diez 1996, Leon \& Bjorndal 2002, Van Dam et al. 2008; but see Blumenthal et al. 2009c, Witt et al. 2010a). It was not possible to ascertain whether the turtles in the present study were foraging on the benthos (i.e. reefs) at these depths or whether, as with other species of marine turtles, they have a greater dietary plasticity and could forage in the pelagic water column (Hatase et al. 2002, Hawkes et al. 2006, McClellan \& Read 2007, Schofield et al. 2010, Gaos et al. 2012). However, Blumenthal et al. (2009b) proposed that deep dives could allow hawksbill turtles to exploit the 'sponge belt' at 80 to $120 \mathrm{~m}$ (see also Ghiold et al. 1994) and may even confer some resilience against the effects of future climate change (Hawkes et al. 2009). Patterns and diversity of fauna in deep offshore waters in the Caribbean are generally not well documented, particularly and unfortunately for the purposes of the present study for Nicaragua, Honduras and Hispaniola (the DR and Haiti; Miloslavich et al. 2010, but see also Leon \& Bjorndal 2002), precluding an estimation of habitat type at foraging home ranges.

Additionally, while threats to marine turtles on the nesting beaches of Nicaragua have been documented (including harvesting of eggs and meat for local consumption; Lagueux 1998), very little is known of the threats in offshore waters, which may include by-catch in shrimping operations and harvest for meat and shell products (Lagueux \& Campbell 2005). While an assessment of threats is lacking, anecdotal evidence suggests that compliance of shrimping vessels in using turtle excluder devices to minimise by-catch of turtles could be low and that harvest for meat at sea does take place (Lagueux \& Campbell 2005).

\section{Regional conservation priorities}

Multiple tracking studies have now independently confirmed that the waters of Nicaragua, and to a lesser extent, Honduras, may be a major terminus for foraging hawksbill turtles (Troëng et al. 2005, Van Dam et al. 2008, Moncada et al. 2012). The lack of data with which to describe both the habitat types and threats to turtles in these waters is a significant obstacle to understanding their ecology and conservation, and we highlight these as major information gaps. The turtles we tracked used the waters of at least 7 different Caribbean nations, all with differing legal architecture protecting hawksbills, but all of these nations have on-going marine turtle research programmes, and hawksbills are protected, at least by law, in 4 of those countries (Dow Piniak \& Eckert 2011). In a recent study, Moncada et al. (2012) suggested that Caribbean-wide conservation of hawksbills could be enhanced by strengthening the legal protection of hawksbills within each nation that hosts them. Particularly for rookeries where a portion of the population does not migrate to foreign waters (e.g. Barbados [Horrocks et al. 2001], Cuba [Moncada et al. 2012], Costa Rica [Troëng et al. 2005], Puerto Rico [Van Dam et al. 2008]), this provides for a realistic management framework that could be implemented immediately.

Acknowledgements. Funding for the transmitters came from the JM Kaplan Foundation award to the World Wildlife Fund, Canada, and from different European institutions: the Spanish International Cooperation Agency (AECI, projects: A/2991/05 and A/5641/06), the Spanish Ministry of Education and Sciences (CGL2006-02936-BOS and CGL201130413) and the General Foundation of the University of Valencia. L.A.H. was supported by the WWF MacArthur project 'Developing an approach to adaptation to climate change in the marine turtles: the hawksbill turtle as an indicator species' to C. Drews. Work was carried out under permit in the DR. L.A.H. is supported by a Biotechnology and Biological Sciences Research Council (BBSRC) post-doctoral fellowship. J.T. and J.A.R. are supported by project Prometeo/2011/40 of Conselleria de Educacio (Generalitat Valenciana) and by the European Union (Marie Curie grants, FP6 \& 7). A.C.B., B.J.G. and M.J.W. were supported by the Darwin Initiative, Natural Environment Research Council (NERC) and the Peninsula Research Institute for Marine Renewable Energy (PRIMaRE). We are grateful to Rory Wilson and 3 anonymous reviewers whose comments improved the manuscript. 


\section{LITERATURE CITED}

Allen ZC, Shah NJ, Grant A, Derand GD, Bell D (2010) Hawksbill turtle monitoring in Cousin Island Special Reserve, Seychelles: an eight-fold increase in annual nesting numbers. Endang Species Res 11:195-200

Anderes BL, Uchida I (1994) Study of hawksbill turtle (Eretmochelys imbricata) stomach contents in Cuban waters. In: Study of the hawksbill turtle in Cuba (I). Ministry of the Fishing Industry, La Habana, Cuba, p 27-40

Beggs JA, Horrocks JA, Krueger BH (2007) Increase in hawksbill sea turtle Eretmochelys imbricata nesting in Barbados, West Indies. Endang Species Res 3:159-168

Block BA, Jonsen ID, Jorgensen SJ, Winship AJ and others (2011) Tracking apex marine predator movements in a dynamic ocean. Nature 475:86-90

Blumenthal J, Solomon JL, Bell CD, Austin TJ and others (2006) Satellite tracking highlights the need for international cooperation in marine turtle management. Endang Species Res 7:1-11

Blumenthal JM, Abreu-Grobois FA, Austin TJ, Broderick AC and others (2009a) Turtle groups or turtle soup: dispersal patterns of hawksbill turtles in the Caribbean. Mol Ecol 18:4841-4853

Blumenthal JM, Austin TJ, Bell CD, Bothwell JB and others (2009b) Ecology of hawksbill turtles, Eretmochelys imbricata, on a Western Caribbean foraging ground. Chelonian Conserv Biol 8:1-10

Blumenthal JM, Austin TJ, Bothwell JB, Broderick AC and others (2009c) Diving behaviour and movements of juvenile hawksbill turtles Eretmochelys imbricata on a Caribbean coral reef. Coral Reefs 28:55-65

> Bograd SJ, Block BA, Costa DP, Godley BJ (2010) Biologging technologies: new tools for conservation. Introduction. Endang Species Res 10:1-7

> Bowen BW, Grant WS, Hillis-Starr Z, Shaver DJ, Bjorndal KA, Bolten AB, Bass AL (2007) Mixed-stock analysis reveals the migrations of juvenile hawksbill turtles (Eretmochelys imbricata) in the Caribbean Sea. Mol Ecol 16:49-60

> Burgman MA, Fox JC (2003) Bias in species range estimates from minimum convex polygons: implications for conservation and options for improved planning. Anim Conserv 6:19-28

Carillo E, Webb GJW, Manolis SC (1999) Hawksbill turtles (Eretmochelys imbricata) in Cuba: an assessment of the historical harvest and its impacts. Chelonian Conserv Biol 3:264-280

Chapman JW, Klaassen RHG, Drake VA, Fossette S and others (2011) Animal orientation strategies for movement in flows. Curr Biol 21:R861-R870

Coyne MS, Godley BJ (2005) Satellite Tracking and Analysis Tool (STAT): an integrated system for archiving, analyzing and mapping animal tracking data. Mar Ecol Prog Ser 301:1-7

Diez CE, Van Dam RP (2007) Mona and Monito Island: Puerto Rico hawksbill turtle research project. Research Report for 2006. National Marine Fisheries Service and Departemento de Recursos Naturales y Ambientales, San Juan, Puerto Rico

Dow Piniak WE \& Eckert KL (2011) Sea turtle nesting habitat in the Wider Caribbean Region. Endang Species Res 15:129-141

> Fanning L, Mahon R, McConney P, Angulo J and others (2007) A large marine ecosystem governance framework.
Mar Policy 31:434-443

> Game ET, Grantham HS, Hobday AJ, Pressey RL and others (2009) Pelagic protected areas: the missing dimension in ocean conservation. Trends Ecol Evol 24:360-369

> Gaos AR, Lewison RL, Yanez IL, Wallace BP and others (2012) Shifting the life-history paradigm: discovery of novel habitat use by hawksbill turtles. Biol Lett 8:54-56

- Gaspar P, Georges JY, Fossette S, Lenoble A, Ferraroli S, Le Maho Y (2006) Marine animal behaviour: neglecting ocean currents can lead us up the wrong track. Proc Biol Sci 273:2697-2702

Ghiold J, Rountree GA, Smith SH (1994) Common sponges of the Cayman Islands. In: Brunt AM, Davies JE (eds) The Cayman Islands: natural history and biogeography. Kluwer Academic Publishers, Dordrecht, p 131-138

Girard C, Sudre J, Benhamou S, Roos D, Luschi P (2006) Homing in green turtles Chelonia mydas: oceanic currents act as a constraint rather than as an information source. Mar Ecol Prog Ser 322:281-289

> Girard C, Tucker AD, Calmettes B (2009) Post-nesting migrations of loggerhead sea turtles in the Gulf of Mexico: dispersal in highly dynamic conditions. Mar Biol 156: 1827-1839

Godley BJ, Blumenthal JM, Broderick AC, Coyne MS, Godfrey MH, Hawkes LA, Witt MJ (2008) Satellite tracking of sea turtles: Where have we been and where do we go next? Endang Species Res 4:3-22

> Godley BJ, Barbosa C, Bruford M, Broderick AC and others (2010) Unravelling migratory connectivity in marine turtles using multiple methods. J Appl Ecol 47:769-778

Guerreiro J, Chircop A, Grilo C, Viras A, Ribeiro R, van der Elst R (2010) Establishing a transboundary network of marine protected areas: diplomatic and management options for the east African context. Mar Policy 34: 896-910

Hart MK, Hyrenbach KD (2009) Satellite telemetry of marine megavertebrates: the coming of age of an experimental science. Endang Species Res 10:9-20

Hatase H, Takai N, Matsuzawa Y, Sakamoto W and others (2002) Size-related differences in feeding habitat use of adult female loggerhead turtles Caretta caretta around Japan determined by stable isotope analyses and satellite telemetry. Mar Ecol Prog Ser 233:273-281

Hawkes LA, Broderick AC, Coyne MS, Godfrey MH and others (2006) Phenotypically linked dichotomy in sea turtle foraging requires multiple conservation approaches. Curr Biol 16:990-995

> Hawkes LA, Broderick AC, Godfrey MH, Godley BJ (2009) Climate change and marine turtles. Endang Species Res $7: 137-154$

> Hawkes LA, Witt MJ, Broderick AC, Coker JW and others (2011) Home on the range: spatial ecology of loggerhead turtles in Atlantic waters of the USA. Divers Distrib 17: $624-640$

> Hill MS (1998) Spongivory on Caribbean reefs releases corals from competition with sponges. Oecologia 117:143-150

Hooker SK, Biuw M, McConnell BJ, Miller PJO, Sparling CE (2007) Bio-logging science: logging and relaying physical and biological data using animal-attached tags. Deep-Sea Res II 54:177-182

Horrocks JA, Vermeer LA, Krueger B, Coyne M, Schroeder BA, Balazs GH (2001) Migration routes and destination characteristics of post-nesting hawksbill turtles satellitetracked from Barbados, West Indies. Chelonian Conserv Biol 4:107-114 
Horrocks JA, Krueger BH, Fastigi M, Pemberton EL, Eckert KL (2011) International movements of adult female hawksbill turtles (Eretmochelys imbricata): first results from the Caribbean's marine turtle tagging centre. Chelonian Conserv Biol 10:18-25

Kamel SJ, Delcroix E (2009) Nesting ecology of the hawksbill turtle, Eretmochelys imbricata, in Guadeloupe, French West Indies from 2000-07. J Herpetol 43:367-376

Kooyman G (2007) Animal-borne instrumentation systems and the animals that bear them: then (1939) and now (2007). Mar Technol Soc J 41:6-8

Lagueux CJ (1998) Marine turtle fishery of Caribbean Nicaragua: human use patterns and harvest trends. PhD dissertation, University of Florida, Gainesville, FL

Lagueux CJ, Campbell CL (2005) Marine turtle nesting and conservation needs on the south-east coast of Nicaragua. Oryx 39:398-405

Leon YM, Bjorndal KA (2002) Selective feeding in the hawksbill turtle, an important predator in coral reef ecosystems. Mar Ecol Prog Ser 245:249-258

Leon YM, Diez CE (1999) Population structure of hawksbill turtles on a foraging ground in the Dominican Republic. Chelonian Conserv Biol 3:230-236

Luschi P, Hays GC, Papi F (2003) A review of long-distance movements by marine turtles, and the possible role of ocean currents. Oikos 103:293-302

Marcovaldi MA, Chaloupka M (2007) Conservation status of the loggerhead sea turtle in Brazil: an encouraging outlook. Endang Species Res 3:133-143

McClellan CM, Read AJ (2007) Complexity and variation in loggerhead sea turtle life history. Biol Lett 3:592-594

McClenachan L, Jackson JB, Newman MJ (2006) Conservation implications of historic sea turtle nesting beach loss. Front Ecol Environ 4:290-296

Meylan A (1988) Spongivory in hawksbill turtles: a diet of glass. Science 239:393-395

Meylan AB (1999) Status of the hawksbill turtle (Eretmochelys imbricata) in the Caribbean region. Chelonian Conserv Biol 3:177-184

> Meylan PA, Meylan AB, Gray JA (2011) The ecology and migrations of sea turtles 8 . Tests of the developmental habitat hypothesis. Bull Am Mus Nat Hist 357:1-70

Miloslavich P, Diaz JM, Klein E, Alvarado JJ and others (2010) Marine biodiversity in the Caribbean: regional estimates and distribution patterns. PLoS ONE 5:e11916

Moncada FG, Hawkes LA, Fish MR, Godley BJ and others (2012) Patterns of dispersal of hawksbill turtles from the Cuban shelf inform scale of conservation and management. Biol Conserv 148:191-199

> Obura D, Harvey A, Young T, Eltayeb M, von Brandis R
(2010) Hawksbill turtles as significant predators on hard coral. Coral Reefs 29:759

Ottenwalder JA (1981) Estudio preliminar sobre el estado, distribución, y biología reproductiva de las tortugas marinas en la República Dominicana. MS thesis, Universidad Autónoma de Santo Domingo

Revuelta O, León YM, Feliz P, Godley BJ, Raga JA, Tomas J (2012) Protected areas host important remnants of marine turtle nesting stocks in the Dominican Republic. Oryx 46:348-358

Richardson JI, Hall DB, Mason PA, Andrews KM, Bjorkland R, Cai Y, Bell R (2006a) Eighteen years of saturation tagging data reveal a significant increase in nesting hawksbill sea turtles (Eretmochelys imbricata) on Long Island, Antigua. Anim Conserv 9:302-307

Richardson PB, Broderick AC, Campbell LM, Godley BJ, Ranger S (2006b) Marine turtle fisheries in the UK overseas territories of the Caribbean: domestic legislation and the requirements of multilateral agreements. J Int Wildl Law Policy 9:223-246

Schofield G, Hobson VJ, Fossette S, Lilley MKS, Katselidis KA, Hays GC (2010) Fidelity to foraging sites, consistency of migration routes and habitat modulation of home range by sea turtles. Divers Distrib 16:840-853

Shillinger GL, Di Lorenzo E, Luo H, Bograd SJ, Hazen EL, Bailey H, Spotila JR (2012) On the dispersal of leatherback turtle hatchlings from Mesoamerican nesting beaches. Proc R Soc Lond B (in press) doi:10.1098/ rspb.2011.2348

Troëng S, Dutton PH, Evans D (2005) Migration of hawksbill turtles Eretmochelys imbricata from Tortuguero, Costa Rica. Ecography 28:394-402

- Van Dam RP, Diez CE (1996) Diving behavior of immature hawksbills (Eretmochelys imbricata) in a Caribbean cliffwall habitat. Mar Biol 127:171-178

Van Dam RP, Diez CE, Balazs GH, Colon LAC, McMillan WO, Schroeder B (2008) Sex-specific migration patterns of hawksbill turtles breeding at Mona Island, Puerto Rico. Endang Species Res 4:85-94

- Wallace BP, Lewison RL, McDonald SL, McDonald RK and others (2010) Global patterns of marine turtle bycatch. Conserv Lett 3:131-142

- Witt M, McGowan A, Blumenthal J, Broderick A and others (2010a) Inferring vertical and horizontal movements of juvenile marine turtles from time-depth recorders. Aquat Biol 8:169-177

Witt MJ, Åkesson S, Broderick AC, Coyne MS and others (2010b) Assessing accuracy and utility of satellitetracking data using Argos-linked Fastloc-GPS. Anim Behav 80:571-581 
Appendix 1. Additional data on migration of hawksbill turtles

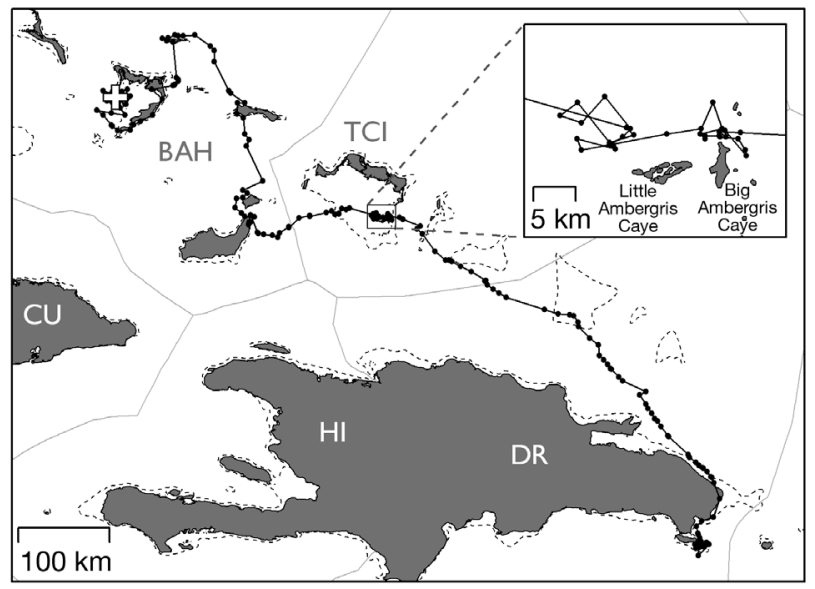

Fig. A1. Migration of Turtle $\mathrm{f}$ through the waters of the Turks and Caicos Islands (TCI) and on to the Bahamas (BAH). Inset shows transit through the Turks and Caicos with a $60 \mathrm{~d}$ residency off Big and Little Ambergris Cayes. Black dashed line: bathymetric contour of 200 m, grey lines: Extents of Exclusive Economic Zones. CU: Cuba, HI: Haiti, DR: Dominican Republic

Table A1. Deployment metrics for adult female hawksbill turtles from the Dominican Republic, including curved carapace length (CCL, $\mathrm{cm}$ ), PTT type, foraging home range size using minimum convex polygons (MCPs) and $\alpha$-hull, and the duration of time tracked at foraging ground. $\left({ }^{*}\right)$ incomplete foraging (the turtle stopped transmitting before departing the foraging ground). (+): complete foraging (the turtle was tracked departing the foraging ground and returning to breed after time spent at foraging ground)

\begin{tabular}{|c|c|c|c|c|c|c|c|c|c|}
\hline Turtle & $\begin{array}{l}\text { CCL } \\
(\mathrm{cm})\end{array}$ & PTT type & $\begin{array}{c}\text { Date } \\
\text { deployed }\end{array}$ & $\begin{array}{c}\text { Deployment } \\
\text { duration } \\
\text { (d) }\end{array}$ & $\begin{array}{l}\text { Foraged } \\
\text { (country) }\end{array}$ & $\begin{array}{c}\text { Max. } \\
\text { displace } \\
(\mathrm{km})\end{array}$ & $\begin{array}{l}\mathrm{MCP} \\
\left(\mathrm{km}^{2}\right)\end{array}$ & $\begin{array}{c}\alpha \text {-hull } \\
\left(\mathrm{km}^{2}\right)\end{array}$ & $\begin{array}{c}\text { Forage } \\
\text { duration } \\
\text { (d) }\end{array}$ \\
\hline a & 92 & Wildlife Computers SPOT5 & 30 Sep 2008 & 613 & Dominican Republic & 368 & $7179^{*}$ & $2240^{*}$ & 576 \\
\hline $\mathrm{b}$ & 81 & Wildlife Computers SPOT5 & 27 Oct 2008 & 710 & Dominican Republic & 231 & $1835^{*}$ & $451^{*}$ & 640 \\
\hline $\mathrm{C}$ & 92 & Wildlife Computers SPOT5 & 22 Dec 2008 & 11 & (tracking failed early) & 126 & $(-)$ & $(-)$ & $(-)$ \\
\hline d & 94 & Wildlife Computers SPOT5 & 19 Sep 2008 & 442 & Nicaragua & 1562 & $4016^{*}$ & $1497^{*}$ & 397 \\
\hline e & 84 & Wildlife Computers SPOT5 & 11 Aug 2008 & 53 & (tracking failed early) & 1014 & $(-)$ & $(-)$ & $(-)$ \\
\hline f & 84 & Wildlife Computers SPOT5 & 01 Nov 2008 & 366 & Bahamas & 792 & $6249^{*}$ & $2627^{*}$ & 225 \\
\hline g & 90 & Kiwisat 101 & 28 Aug 2008 & 1302 & Nicaragua & 1412 & 2455 & $1022+$ & 593 \\
\hline $\mathrm{h}$ & 90 & Kiwisat 101 & 29 Aug 2008 & 1081 & Nicaragua & 1666 & 18190 & $4422+$ & 891 \\
\hline $\mathrm{i}$ & 84 & Kiwisat 101 & 07 Aug 2009 & 137 & Honduras & 1424 & $322^{*}$ & $181^{*}$ & 93 \\
\hline j & 87 & Kiwisat 101 & 01 Sep 2009 & 866 & Nicaragua & 1481 & 10071 & $2122+$ & 594 \\
\hline \multicolumn{2}{|c|}{ MEDIAN } & & & 558 & & 1213 & 5133 & 1810 & 585 \\
\hline
\end{tabular}

Editorial responsibility: Rory Wilson,

Swansea, UK
Submitted: January 5, 2012; Accepted: April 20, 2012

Proofs received from author(s): July 18, 2012 